\title{
Desired Gain Selection Indices for Pre-Weaning Body Weights in Zaraibi Male Kids in Egypt

\author{
Ali Ali El-Raghi ${ }^{1}$, Abdullah Ali Ghazy ${ }^{* 2}$ and Ibrahim Atta Abu El-Naser ${ }^{1}$ \\ ${ }^{1}$ Animal Production Department, Faculty of Agriculture, 34517, Damietta University, Egypt \\ ${ }^{2}$ Department of Animal Production, Faculty of Agriculture, Suez Canal University, Ismailia 41522, Egypt
}

Received: $17 / 5 / 2020$

\begin{abstract}
The aim of the current study was to estimate the genetic parameters and evaluate various desired-gain selection indices for pre-weaning live body weights of Zaraibi male kids in Egypt. From 2005 to 2012, data of 763 does mated with 75 bucks of Zaraibi goats raised at El-Serw Experimental Station belonging to the Animal Production Research Institute were collected. Data were analyzed with REML using animal model to determine genetic parameters and using SAS to construct different desired-gain selection indices. Direct heritability $\left(\mathrm{h}_{\mathrm{d}}^{2}\right)$ for BW, W30, W60 and WW were $0.25,0.22,0.31$ and 0.35 , respectively. Corresponding maternal heritability $\left(\mathrm{h}_{\mathrm{m}}^{2}\right)$ for aforementioned traits were $0.145,0.141,0.099$ and 0.073 , respectively. While total heritability $\left(\mathrm{h}_{\mathrm{t}}{ }_{\mathrm{t}}\right)$ above traits were $0.25,0.38,0.48,0.49$ and 0.34 , respectively. The direct-maternal genetic correlations $\left(\mathrm{r}_{\mathrm{dm}}\right)$ were positive for W30 (0.35) and W60 (0.47), while negative for BW (-0.23) and WW (-0.19). Genetic correlations $\left(\mathrm{r}_{\mathrm{d} 1 \mathrm{~d} 2}\right)$ among studies traits ranged from 0.80 to 0.95 , while phenotypic correlations $\left(\mathrm{r}_{\mathrm{p} 1 \mathrm{p} 2}\right)$ among all traits ranged from 0.69 to 0.84 . Comprisable between selection indices was the highest number of generations required $(\mathrm{T})$ to attain the pre-estimated goals was 5.6143 in $\mathrm{I}_{4}$. In contrast, the lowest number of generations required $(\mathrm{T})$ was 2.0220 in $\mathrm{I}_{14}$. Therefore, $\mathrm{I}_{14}$ was considered the best selection index lead to save time and efforts for genetic improvement of studied traits in Zaraibi male kids in Egypt.
\end{abstract}

Keywords: Zaraibi goat, live body weights, desired-gain and selection indices

\section{INTRODUCTION}

Goats in Egypt are nearly 5 million heads (FAO, 2017). Zaraibi goats, also called Egyptian Nubian goats, are the most pronounced dairy goat among the local goat breeds in Egypt. Gall (1981), Devendra and Mc Leroy (1982) stated that this breed is a progenitor for the standard international Anglo-Nubian. The population size of Zaraibi breed is small, which estimated as $2 \%$ of Egypt's total goat population, the breed has a good reputation in the Near East and Egypt due to its high milk production and prolificacy (Galal et al., 2005).

It is very important to study the Zaraibi goats under variation environmental conditions and in a large size for development breeding strategies (Marai et al., 2002). Lopes et al. (2013) reported that the improvement in traits was when used the selection indices in dairy goats and added that the use of indices relies on the definition of selection and on the measurability of the selection criteria. El-Awady (2009) reported that the amount of weight given to each trait in the selection index depends on genetic and phenotypic variance and co-variances among traits.

In Kutci goats, Yadav et al. (2005) indicated that the highest genetic gain in body weight at 12 months will be achieved using selection index included body weight at 3 and 9 months. The relative economic value for all traits in aggregate genotype is essential of selection indices. Assessment of economic value is a stressful process and it is related to change the price trend in the market. A selection index for achieving prearranged desired genetic gain, where describe aggregate genotype and determine of relative economic values of all traits are not required (Pešek and Baker, 1969). Furthermore, In Zaraibi goat, Desoky (2012) indicated that the application of selection indices

\footnotetext{
*Corresponding author e-mail: ghazy@agr.suez.edu.eg
}

strategy will result in an expected genetic gain for weaning weight about $0.592 \mathrm{~kg}$ per generation. Therefore, the aim of this study was to establish varied desired-gain selection indices to improve pre-weaning body weight in Egypt's Zaraibi male kids.

\section{MATERIALS AND METHODS}

\section{Data and management:}

Data used were collected from the Zaraibi flock raised in El-Serw Experimental Station over a continuous span of 8 years (2005-2012), belonging to the Institute for Animal Production Research (APRI), Ministry of Agriculture. The data consisted of 1419, 1346, 1298 and 1283 records for body weights at birth (BW), body weight at 30 days (W30), body weight at 60 days (W60) and weaning weight (WW), respectively. The data relevant to 763 does presented to 75 buck. Mating system on the farm, where the does are divided into two groups per year. The first group was mating in June and another group was mating in October. Does don't mate with buck before 18 month of age or $30 \mathrm{~kg}$ of live body weight. The kids after birth were ear-tagged, and kept with their dams over suckling period until weaning at 3 months of age. The kids were weighted within 24 hours of birth and then monthly until 18 months of age. The kids after weaning on concentrate mixture and green Egyptian clover (Trifolium alexandrinum) in Winter, while at Summer were fed on concentrate mixture and crop stubbles or rice straw or green fodder (if available). The animals were housed in semi-open barns and fed diets to meet the nutritional requirements of APRI depending on NRC, 2007.

The food was provided to animals twice daily before grazing in the morning and after grazing in the evening. The animals were allowed to drink water three times daily and minerals blocks were available at all 
times. Two weeks before the beginning of mating season supplementary concentrate was offered at a rate of about $0.25 \mathrm{~kg} / \mathrm{doe} / \mathrm{day}$, also the supplementary feed was given during the last 2-4 weeks of pregnancy and through the first week of lactation, if available (ElAwady et al., 2019).

\section{Statistical analysis:}

\section{Variance and covariance}

Variance and covariance components were obtained with Derivative-free restricted maximum likelihood (REML) procedure using the MTDFREML program of (Boldman et al., 1995) according to the following model:

\section{Where:}

$$
Y=X b+Z_{d} d+Z_{m} m+Z_{c} c+e
$$

$\mathrm{Y}=\mathrm{a}$ vector of observations.

$\mathrm{b}=\mathrm{a}$ vector of fixed effects (Birth type, month and year of kidding) with an incidence matrix.

$\mathrm{d}, \mathrm{m}, \mathrm{c}, \mathrm{e}=$ vectors of direct additive genetic effects, maternal genetic effects, permanent environmental effect of dam and the residual, respectively.

$\mathrm{X}, \mathrm{Z}_{\mathrm{d}}, \mathrm{Z}_{\mathrm{m}}, \mathrm{Z}_{\mathrm{c}}=$ incidence matrices relating observations to $b, d, m$ and $c$, respectively.

Direct and maternal heritabilites were calculated according to the following formulas: $h^{2}{ }_{d}=\sigma^{2}{ }_{d} / \sigma_{p}^{2}$; $\mathrm{h}_{\mathrm{m}}^{2}=\sigma_{\mathrm{m}}^{2} / \sigma_{\mathrm{p}}^{2}$, while repeatability (r) and total heritability $\left(\mathrm{h}^{2} \mathrm{t}\right)$ were calculated according to (Willham, 1972):

$\mathrm{r}=\left[\left(\sigma_{\mathrm{d}}^{2}+0.5 \sigma_{\mathrm{m}}^{2}+1.5 \sigma_{\mathrm{dm}}+\sigma_{\mathrm{pe}}^{2}\right) / \sigma_{\mathrm{p}}^{2}\right]$

$\mathrm{h}_{\mathrm{t}}^{2}=\left[\left(\sigma_{\mathrm{d}}^{2}+0.5 \sigma_{\mathrm{m}}^{2}+1.5 \sigma_{\mathrm{dm}}\right) / \sigma_{\mathrm{p}}^{2}\right]$

Where: $\sigma_{p}^{2}=\sigma_{d}^{2}+\sigma_{m}^{2}+\sigma_{d m}+\sigma_{p e}^{2}+\sigma^{2}$.

\section{Selection indices:}

Different desired-gain selection indices were estimated using SAS program (SAS, 2012). Desiredgain selection indices were constructed according to Yamada et al. (1975). Selection was constructed based on the index: $I=b^{\prime} X$.

Where: $\mathrm{X}=$ phenotypic records and $\mathrm{b}=$ selection index coefficient for traits was calculated as: $b=G^{\prime} Q$.

Where: $\mathrm{G}=$ genetic variance-covariance matrix for traits in the index, and $Q=$ desired gain matrix for the traits in the index.

The indices were evaluated in terms of the number of generations required to achieve the pre-defined/ desired gains and correlated responses. Furthermore, desired genetic changes for various traits $(Q)$ were calculated as the difference between desired and observed means. Intended performances/improvement and hence desired gains/genetic changes for studied traits (Lwelamira and Kifaro, 2010). Values of partial regression coefficient and phenotypic co-variance matrix were utilized to calculate values of index variance as: $\sigma_{I}^{2}=\bar{b} P b$. Furthermore, we used $\sigma_{I}$ to calculate number of generations required $(\mathrm{T})$ to attain the goal as: $T=\frac{\sigma_{I}}{i_{I}}=\frac{(\bar{b} P b)^{\frac{1}{2}}}{i_{I}}$

Where: $\bar{b}$ is the transpose of (b) vector of partial regression coefficients.

$\mathrm{P}=$ phenotypic variance-covariance matrix.

The expected genetic change $(\Delta \mathrm{G})$ for each trait, after one generation of selection on the index $(i=1)$ was obtained by solving either of the following equations (Van der Werf and Goddard, 2003):

$$
\Delta G_{i}=\frac{i b^{\prime} G_{i}}{\sigma_{i}}
$$

Where: $\mathrm{i}=$ Selection intensity; $\sigma_{i}=$ Standard deviation of the index; $G_{i}=$ the $i^{\text {th }}$ column of the $G$ matrix.

\section{RESULTS AND DISCUSSION}

The current unadjusted means of BW, W30, W60 and WW were, $1.733,5.309,8.229$ and $11.087 \mathrm{~kg}$, respectively (Table 1). The present results were in general close up with those reported by Aboul-Naga et al. (2012) and El-Moghazy et al. (2015) for the same flock on another set of data and lower than those reflected by Tesema et al. (2017) in Central Highland $\mathrm{x}$ Boer crossbred goats and Mohammed et al. (2018) in Saudi Ardi goat breed and Damascus goat breed and their crosses for different live body weights from birth until weaning of kids. Those differences may be due to the variations in gene combinations related to growth rates between breeds. Estimate of the coefficient of variation for BW was lower than other traits of live body weights which these results agree with found by El-Awady (2011) in Barki Sheep raised in Egypt, which showed that the low effect of environment on birth weight.

Table (1): Unadjusted mean, Standard error (SE) and Coefficient of variation (CV \%) for studied traits

\begin{tabular}{lcccc}
\hline Trait Kg & Records & Mean & SE & CV\% \\
\hline BW & 1419 & 1.733 & 0.007 & 15.246 \\
W30 & 1346 & 5.309 & 0.025 & 17.264 \\
W60 & 1298 & 8.229 & 0.043 & 18.870 \\
WW & 1283 & 11.087 & 0.058 & 18.896 \\
\hline
\end{tabular}

$\mathrm{BW}=$ birth weight, $\mathrm{W} 30=$ weight at 30 -day $\mathrm{W} 60=$ body weight at 60 days and $\mathrm{WW}=$ weaning weight.

\section{Genetic parameters}

Direct heritability $\left(\mathrm{h}_{\mathrm{d}}^{2}\right)$ for $\mathrm{BW}, \mathrm{W} 30, \mathrm{~W} 60$ and WW were moderate $0.25,0.22,0.31$ and 0.35 , respectively (Table 2). The current estimates of $\left(\mathrm{h}_{\mathrm{d}}^{2}\right)$ were higher than those reviewed by Sadegh et al. (2013) in Iranian Adani goats for BW and WW were 0.23 and 0.18 , respectively, Mohammed et al. (2018) in Saudi Ardi goat $x$ Damascus goat for BW was 0.15 and AlSaef (2013) in Damascus goats were 0.19 and 0.12 , respectively. 
Table (2): Estimates of genetic parameters for investigated body weights in Zaraibi male kids

\begin{tabular}{|c|c|c|c|c|c|c|c|c|c|c|c|}
\hline Trait & $\sigma_{d}^{2}$ & $\sigma_{m}^{2}$ & $\sigma_{\mathrm{dm}}$ & $\sigma_{p e}^{2}$ & $\sigma_{e}^{2}$ & $\sigma_{p}^{2}$ & $h^{2}{ }_{d}$ & $h^{2}{ }_{m}$ & $r_{d m}$ & $\mathbf{r}$ & $\mathbf{h}_{t}^{2}$ \\
\hline BW & 0.017 & 0.010 & -0.003 & 0.007 & 0.038 & 0.069 & 0.25 & 0.145 & -0.23 & 0.36 & 0.25 \\
\hline W30 & 0.184 & 0.118 & 0.052 & 0.071 & 0.415 & 0.840 & 0.22 & 0.141 & 0.35 & 0.47 & 0.38 \\
\hline W60 & 0.750 & 0.239 & 0.201 & 0.218 & 1.003 & 2.411 & 0.31 & 0.099 & 0.47 & 0.58 & 0.49 \\
\hline WW & 1.554 & 0.318 & -0.133 & 0.286 & 2.364 & 4.389 & 0.35 & 0.073 & -0.19 & 0.41 & 0.34 \\
\hline
\end{tabular}

direct genetic variance $\left(\sigma_{\mathrm{d}}^{2}\right)$; maternal genetic variance $\left(\sigma_{\mathrm{m}}^{2}\right)$; maternal permanent environmental variance $\left(\sigma_{\mathrm{pe}}^{2}\right)$; residual variance $\left(\sigma_{\mathrm{e}}^{2}\right)$; direct-maternal genetic covariance $\left(\sigma_{\mathrm{dm}}\right)$; phenotypic variance $\left(\sigma_{\mathrm{p}}^{2}\right)$; correlation between direct and maternal genetic $\left(\mathrm{r}_{\mathrm{dm}}\right)$; direct heritability $\left(\mathrm{h}_{\mathrm{d}}^{2}\right)$; maternal heritability $\left(\mathrm{h}_{\mathrm{m}}^{2}\right)$; total heritability $\left(\mathrm{h}_{\mathrm{t}}^{2}\right)$; repeatability $(\mathrm{r})$

Maternal heritability $\left(\mathrm{h}_{\mathrm{m}}^{2}\right)$ for BW, W30, W60 and WW were slightly and being $0.145,0.141,0.099$ and 0.073 , respectively. The present appreciation of $\left(\mathrm{h}_{\mathrm{m}}^{2}\right)$ were complied with those determined by the pool of recent authors in different animal models Gholizadeh et al. (2010) in Raeini goats, Sadegh et al. (2013) in Iranian Adani goats, Baneh et al. (2012) in Naeini goats for $\mathrm{BW}$ and $\mathrm{WW}$ were ranged from 0.016 to 0.33 and 0.01 to 0.32 , respectively). Likewise, Boujenane and El Hazzab (2008) find out $\mathrm{h}^{2}$ m for BW and W30 in Draa goats were varied from 0.04 to 0.21 and 0.00 to 0.18 , respectively.

Moreover, the actual results of were $\mathrm{h}_{\mathrm{m}}^{2}$ lower than the estimates of Aboul-Naga et al. (2012) on Zaraibi goats (BW and WW were 0.20 and 0.14, respectively) and Zhang et al. (2009) in Boer goats (WW were ranged from 0.26 to 0.43 and 0.16 to 0.30 , respectively). On the other hand, the current estimates were higher of $\mathrm{h}_{\mathrm{m}}^{2}$ than reviewed by Snyman (2012) in Angora goats for BW was 0.10 and Thomas et al. (2016) in Kiko $\times$ Boer goats for WW was 0.04

Total heritability $\left(\mathrm{h}^{2} \mathrm{t}\right)$ for BW, W30, W60, and WW were moderate and being $0.25,0.38,0.49$ and 0.34 , respectively. These results suggest that mass selection would be very effective in improving studied traits. Direct- maternal genetic correlation $\left(\mathrm{r}_{\mathrm{dm}}\right)$ were positive for W30 (0.35) and W60 (0.47), on the contrary for BW and WW were negative -0.23 and -0.19 , respectively. The present results are comparable to those reported by some investigators (Rashidi et al., 2008) in Markhoz goats, Boujenane and El Hazzab (2008) in Draa goats, Zhang et al. (2009) in Boer goat, El-Awady (2011), Osman (2013) in Zaraibi goats and Sadegh et al. (2013) in Iranian Adani goats).

Estimates of repeatability for BW, W30, W60 and WW were $0.36,0.47,0.58$ and 0.41 , respectively presented in Table (2). The existing study for BW and WW were lower ( 0.61 and 0.52 , respectively) than those stated by Alade et al. (2010) in Africa goats. Vice versa, the appreciation exists of repeatability for W60 and WW were higher than the estimates of Kuthu et al. (2017) in Teddy (0.41 and 0.38 , respectively).

Estimates of different correlations among investigated traits in Zaraibi male kids are given in Table (3). Genetic and phenotypic correlations were lower between non-adjacent weights than adjacent ones. They were positive, indicating no genetic and phenotypic antagonism among them. Genetic correlations were ranged from 0.80 (BW and $\mathrm{WW}$ ) to 0.95 (BW and W30). Meanwhile, phenotypic correlations were varied from 0.69 (BW and WW) to 0.84 (W60 and WW). In this respect, positive genetic and phenotypic correlations between live body weights in different breeds were obtained by several authors (A1Shorepy et al., 2002; Shaat et al., 2007; Ballal et al., 2008; Haque et al., 2012; Sadegh et al., 2013; Baneh et al., 2012). In contrast; Mugambi et al. (2007) detected negative phenotypic correlation in Kenya Dual Purpose Goats between BW and WW.

Table (3): Estimates of different correlations among investigated traits in Zaraibi male kids

\begin{tabular}{lccccc}
\hline Correlated traits & $\mathrm{r}_{\mathrm{d} 1 \mathrm{~d} 2}$ & $\mathrm{r}_{\mathrm{m} 1 \mathrm{~m} 2}$ & $\mathrm{r}_{\mathrm{pelp} 2}$ & $\mathrm{r}_{\mathrm{ele} 2}$ & $\mathrm{r}_{\mathrm{p} 1 \mathrm{p} 2}$ \\
\hline BW-W30 & 0.95 & 0.86 & 0.81 & 0.34 & 0.79 \\
BW-W60 & 0.86 & 0.81 & 0.68 & 0.27 & 0.73 \\
BW-WW & 0.80 & 0.72 & 0.61 & 0.22 & 0.69 \\
W30-W60 & 0.91 & 0.77 & 0.78 & 0.85 & 0.83 \\
W30-WW & 0.88 & 0.74 & 0.69 & 0.76 & 0.75 \\
W60-WW & 0.90 & 0.86 & 0.84 & 0.86 & 0.84 \\
\hline
\end{tabular}

direct genetic correlation $\left(\mathrm{r}_{\mathrm{dld} 2}\right)$; maternal genetic correlation $\left(\mathrm{r}_{\mathrm{m} 1 \mathrm{~m} 2}\right)$; maternal permanent environmental correlation $\left(\mathrm{r}_{\mathrm{pelpe} 2}\right)$; environmental correlation $\left(\mathrm{r}_{\mathrm{ele} 2}\right)$; phenotypic correlation $\left(\mathrm{r}_{\mathrm{p} 1 \mathrm{p} 2}\right)$. 
Maternal genetic correlations between all investigated traits were positive and ranged from 0.72 (BW and WW) to 0.86 (BW and W30) and (W60 and WW), these indicated the selection on maternal potentials for any trait could result in an increase in other traits. The current results agree with El-Awady et al. (2019) in Zaraibi goats. Environmental correlations were positive among all traits. Which the Minimum estimate (0.22) was observed between $\mathrm{BW}$ and WW, while the maximum estimate $(0.86)$ was found between W60 and WW. As will, the lowest estimation of permanent environmental correlation was 0.61 (BW and WW) while the highest value was 0.84 (W60 and WW). These results correspond with showed by El-Awady (2011) in Barki Sheep in Egypt.

\section{Selection index}

Expected genetic gains per generation of BW, W30, W60 and WW (using selection intensity (i) $=1$ only for compression), and required number of generations $(\mathrm{T})$ to attain goal of desired genetic gain in Zaraibi male kids begin $0.25,0.5,1$ and $1.5 \mathrm{~kg}$, respectively (Table 4). The highest values for genetic gains of all traits of kids were $0.069, \mathrm{~kg}$ for $\mathrm{BW}$ in index $1_{6}$ (BW and W60), 0.220, kg for W30 in index $\mathrm{I}_{4}(\mathrm{~W} 30$ and W60), 0.4875, kg for W60 in index $\mathrm{I}_{10}$ (W60 and $\mathrm{WW}$, $0.7418, \mathrm{~kg}$ for $\mathrm{WW}$ in index $\mathrm{I}_{14}(\mathrm{WW})$. On the contrary, the lowest values of genetic gain for traits were obtained $0.0246, \mathrm{~kg}$ for $\mathrm{BW}$ in index $\mathrm{I}_{14}(\mathrm{WW})$, 0.089 and $0.1781, \mathrm{~kg}$ for $\mathrm{W} 30$ and $\mathrm{W} 60$, respectively in index $\mathrm{I}_{4}$ (W30, W60 and WW), while the lowest value for $\mathrm{WW}$ was $0.2317, \mathrm{~kg}$ in index $\mathrm{I}_{5}$ (BW and $\mathrm{W} 30$ ). Compare efficiency of these indices were judged based on number of generations required to attain the preestimated goals in Table 3, find out the index $\mathrm{I}_{14}$ which incorporated weaning weight required minimum number of generations (2.022) to attain genetic gain.

While maximum number of generations (5.6143) to attain genetic gain observed in index $1_{4}$ which incorporated $\mathrm{W} 30, \mathrm{~W} 60$ and $\mathrm{WW}$. Thus, $\mathrm{I}_{14}$ was adjudges as the best selection index lead to save time and efforts for genetically improvement for studied traits and reaching the best weight at weaning in Zaraibi male kids.

Table (4): Expected genetic changes $(\Delta \mathrm{G}, \mathrm{kg})$ per generation and the number of generations required to attain desired genetic gain $(\mathrm{T})$ of studied traits in Zaraibi male kids for different selection indices

\begin{tabular}{|c|c|c|c|c|c|c|c|c|c|c|c|c|c|}
\hline \multirow[t]{2}{*}{$\mathbf{I}$} & \multicolumn{4}{|c|}{ Selection criterion } & \multicolumn{4}{|c|}{ b-values } & \multicolumn{4}{|c|}{$\begin{array}{c}\text { Expected genetic change }(\Delta \mathrm{G}, \mathbf{k g}) \\
\text { per generation }\end{array}$} & \multirow[t]{2}{*}{$\mathbf{T}$} \\
\hline & & & & & BW & W30 & W60 & $\mathbf{W W}$ & BW & W30 & W60 & WW & \\
\hline $\mathbf{I}_{1}$ & BW & W30 & W60 & --- & 14.525 & -2.802 & 1.659 & --- & 0.0604 & 0.1208 & 0.2417 & 0.3282 & 4.1360 \\
\hline $\mathbf{I}_{2}$ & BW & W30 & --- & WW & 13.850 & -1.169 & --- & 0.775 & 0.0645 & 0.1290 & 0.2644 & 0.3872 & 3.8735 \\
\hline $\mathbf{I}_{3}$ & BW & --- & W60 & WW & 13.432 & --- & -1.040 & 1.169 & 0.0642 & 0.1269 & 0.2568 & 0.3852 & 3.8936 \\
\hline $\mathbf{I}_{4}$ & --- & W30 & W60 & WW & --- & 7.485 & -5.433 & 2.635 & 0.0199 & 0.0890 & 0.1781 & 0.2671 & 5.6143 \\
\hline $\mathbf{I}_{5}$ & BW & W30 & --- & --- & 13.238 & 0.441 & --- & --- & 0.0687 & 0.1375 & 0.2156 & 0.2317 & 3.6338 \\
\hline $\mathbf{I}_{6}$ & BW & --- & W60 & --- & 12.604 & --- & 0.526 & --- & 0.0690 & 0.1590 & 0.2762 & 0.3212 & 3.6197 \\
\hline $\mathbf{I}_{7}$ & BW & --- & --- & WW & 12.421 & --- & --- & 0.552 & 0.0677 & 0.1602 & 0.3071 & 0.4067 & 3.6875 \\
\hline $\mathbf{I}_{8}$ & --- & W30 & W60 & --- & --- & 1.532 & 0.645 & --- & 0.0350 & 0.2207 & 0.4414 & 0.5198 & 2.2651 \\
\hline $\mathbf{I}_{9}$ & --- & W30 & --- & WW & --- & 1.510 & --- & 0.616 & 0.0327 & 0.2056 & 0.4554 & 0.6170 & 2.4310 \\
\hline $\mathbf{I}_{10}$ & --- & --- & W60 & WW & --- & --- & 0.433 & 0.694 & 0.0276 & 0.1925 & 0.4875 & 0.7313 & 2.0509 \\
\hline $\mathbf{I}_{11}$ & BW & --- & --- & --- & 14.021 & --- & --- & --- & 0.0674 & 0.1196 & 0.1815 & 0.1954 & 3.7046 \\
\hline $\mathbf{I}_{12}$ & --- & W30 & --- & --- & --- & 2.708 & --- & --- & 0.0344 & 0.2013 & 0.3669 & 0.3915 & 2.4826 \\
\hline $\mathbf{I}_{13}$ & --- & --- & W60 & --- & --- & --- & 1.332 & --- & 0.0308 & 0.2165 & 0.4833 & 0.6259 & 2.0686 \\
\hline $\mathbf{I}_{14}$ & --- & --- & --- & WW & --- & --- & --- & 0.965 & 0.0246 & 0.1712 & 0.4639 & 0.7418 & 2.0220 \\
\hline
\end{tabular}


Faid-Allah (2014) constructed two desired selection indices in Friesian heifers, the desired gains for the first index were $1,1.5,1.75$ and $2 \mathrm{~kg}$ for $\mathrm{BW}$, $\mathrm{W} 30$, W60 and WW, respectively and the number of generations required to attain this goal was 2.071 generations $(\mathrm{i}=1)$ and 5.91 generation $(\mathrm{i}=0.35)$, while the desired gains for the second index were $1,1.5,1.5$ and $2 \mathrm{~kg}$ for those traits and the number of generations required to attain this goal were 1.931 generation $(\mathrm{i}=1)$ and 5.5171 generation $(i=0.35)$. He added that it could be using the second index for genetic improvement of pre-weaning body weights to save efforts and time. ElWakil and Fooda (2014) in Dhofari goat constructed selection index contained only birth weight and founded that genetic improvement was 0.01, kg. Recently, ElRaghi (2019) in Zaraibi goats achieved expected genetic gain for the same studied traits ranged from 0.028 to $0.060,0.102$ to $0.247,0.132$ to 0.269 and 0.234 to $0.338, \mathrm{~kg}$ respectively using different types from selection indices (General, reduced and sub-selection indices).

\section{CONCLUSION}

The present investigation revealed modest estimates of direct and total heritability for pre-weaning body weights and high genetic and phenotypic correlations for these traits. These results suggested that including these traits in selection indices could lead to genetic improvement for these traits. Moreover, the findings for the current study confirmed that the index $\mathrm{I}_{14}$ showed the lowest number of generations (2.022) to attain the goal of genetic gain for pre-weaning body weights. Thus, using selection index $\mathrm{I}_{14}$ would lead to advance the efficiency of response to aggregate genotype and would lead to save time and efforts for genetic improvement of these traits in Zaraibi male kids.

\section{ACKNOWLEDGMENT}

We are grateful to the staff in El-Serw Experimental Station and Animal Production Research Institute, for allowing us to work on data.

\section{REFERENCES}

Aboul-Naga, A. M., A. Hamed, I. Shaat and M. M. S. Mabrouk (2012). Genetic improvement of Egyptian Nubian goats as sub-tropical dairy prolific breed. Small Ruminant Research, 102(2-3): 125-130.

Al-Saef, A. M. (2013). Genetic and phenotypic parameters of body weights in Saudi Aradi goat and their crosses with Syrian Damascus goat. Small Ruminant Research, 112(1-3): 3538 .

Al-Shorepy, S. A., G. A. Alhadrami and K. Abdulwahab (2002). Genetic and phenotypic parameters for early growth traits in Emirati goat. Small Ruminant Research, 45(3): 217223.

Alade, N. K., M. A. Dilala and A. O. Abdulyekeen (2010). Phenotypic and genetic parameter estimates of litter size and body weights in goats. International Journal of Science and Nature, 1(2): 262-266.

Ballal, K. M. E., M. A. Ahmed and L. M. A. Musa (2008). Estimates of phenotypic and genetic parameters of growth traits in the Sudanese Nubian goat. Res J Anim Vet Sci, 3: 9-14.

Baneh, H., M. Najafi and G. Rahimi (2012). Genetic parameter estimates for early growth traits in Naeini goat. Animal Production Science, 52(11): 1046-1051.

Boldman, K. G., L. A. Kriese, L. D. Van Vleck and S. D. Kachman (1995). A manual for use of MTDFREML: a set of programs to obtain estimates of variances and covariances.

Boujenane, I. and A. El Hazzab (2008). Genetic parameters for direct and maternal effects on body weights of Draa goats. Small Ruminant Research, 80(1-3): 16-21.

Council, N. R. (2007). Nutrient Requirements of Small Ruminants: Sheep, Goats, Cervids, and New World Camelids. The National Academies Press. https://doi.org/10.17226/11654

Desoky, A. L. (2012). Selection indices for genetic improvement of some productive and reproductive traits in Zaraibi goats. Mansoura University, Egypt.

Devendra, C. and G. B. McLeroy (1982). Goat and sheep production in the tropics. $\left(1^{\text {st }} \mathrm{Ed}\right)$ Longman Group Ltd., London, pp. 271.

El-Awady, H. G. (2009). Calculation of the economic values for some udder health traits to estimate the profitability of the selection indices for dairy cows in Egypt. J. Agric. Res. Kafrelsheikh Univ., 35: 384- 401.

El-Awady, H. G. (2011). Different animal models for estimating genetic parameters of Barki sheep in Egypt. Journal of American Science, 7(9): 882887.

El-Awady, H. G., M. M. El-Moghazy, I. A. M. A. ElNaser and A. A. El-Raghi (2019). Direct and maternal genetic trend estimates for growth traits of Zaraibi goats in Egypt using multivariate animal Models. Int. J. Modern Biol. Med, 10(1): 1-19.

El-Moghazy, M. M., H. R. Metavi, E. Faid-Allah and A. A. El-Raghi (2015). Genetic and non genetic factors affecting body weight traits in Zaraibi goat in Egypt. Journal of Agricultural Research Kafr El-Shaikh Univesity, 41(1): 27-40.

El-Raghi, A. A. (2019). Genetically evaluation for some productive traits in Zaraibi goats. Damietta University, Egypt.

El-Wakil, S. I. and T. A. Fooda (2014). Selection index for some body measurements towards improving milk production in Dhofari goat. 9(1): 1-8.

Faid-Allah, E. (2014). Restricted, Multi-Source and Desired Gain Selection Indices for PreWeaning Body Weights in Friesian Heifers in Egypt. Journal of Animal and Poultry Production, 5(12): 839-850.

FAO, S. (2017). Food and Agricultural Organization of the United Nations; Statistics Division. 
Galal, S., F. Abdel-Rasoul, M. R. Anous and I. Shaat (2005). On-station characterization of small ruminant breeds in Egypt. Characterization of Small Ruminant Breeds in West Asia and North Africa, 2: 141-193.

Gall, C. (1981). Goat Production ( $1^{\text {st }}$ ed.). Academic press, London, New York, pp. 619.

Gholizadeh, M., G. R. Mianji, M. Hashemi and H. Hafezian (2010). Genetic parameter estimates for birth and weaning weights in Raeini goats. Czech J Anim Sci, 55: 30-36.

Haque, M. N., S. S. Husain, M. A. M. Y. Khandoker and A. S. Apu (2012). Selection for Black Bengal breeding bucks on progeny growth performance at nucleus breeding flock. International Research Journal of Applied Life Sciences, 1(4).

SAS Institute. (2012). SAS/OR 9.3 User's Guide: Mathematical Programming Examples. SAS institute.

Kuthu, Z. H., K. Javed, M. E. Babar, A. Sattar and M. Abdullah (2017). Estimation of genetic parameters for pre-weaning growth traits in teddy goats. Journal of Animal \& Plant Sciences, 27(5): 1408-1414.

Lopes, F. B., M. C. da Silva, E. S. Miyagi, M. C. S. Fioravanti, O. Facó and C. Mcmanus (2013). Comparação de índices de seleção de caprinos leiteiros em regiões tropicais. Acta Scientiarum - Animal Sciences, 35(3): 321-328. https://doi.org/10.4025/actascianimsci.v35i3.16 049

Lwelamira, J. and G. C. Kifaro (2010). Desired-gain selection indices for improving performance of two Tanzania local chicken ecotypes under intensive management. African Journal of Agricultural Research, 5(2): 133-141.

Marai, I. F. M., E. I. Abou-Fandoud, A. H. Daader and A. A. Abu-Ella (2002). Reproductive doe traits of the Nubian (Zaraibi) goats in Egypt. Small Ruminant Research, 46(2-3): 201-205.

Mohammed, K. M., M. A. K. EL-den and A. Y. Dahmoush (2018). Heritability and variance components estimates for growth traits in Saudi Ardi goat and Damascus goat and their crosses. Asian Pacific Journal of Reproduction, 7(1): 39-46.

Mugambi, J. N., J. W. Wakhungu, B. O. Inyangala, W. B. Muhuyi and T. Muasya (2007). Evaluation of the performance of the Kenya Dual Purpose Goat composites: Additive and non-additive genetic parameters. Small Ruminant Research, 72(2-3): 149-156.

Osman, M. A. (2013). Estimates of direct and maternal effects for early growth traits of Zaraibi goats. Egyptian Journal of Sheep and Goat Sciences, 65(1242): 1-16.

Pešek, J. and R. J. Baker (1969). Desired improvement in relation to selection indices. Canadian Journal of Plant Science, 49(6): 803-804.

Rashidi, A., M. Sheikhahmadi, J. Rostamzadeh and J. N. B. Shrestha (2008). Genetic and phenotypic parameter estimates of body weight at different ages and yearling fleece weight in Markhoz goats. Asian-Australasian Journal of Animal Sciences, 21(10): 1395-1403.

Sadegh, Y. M., V. T. Rasoul, E. J. K. Naser and A. Mehdi (2013). Estimation of genetic parameters for direct and maternal effects of growth traits in Iranian Adani goats. Annals of Biological Research, 4(7): 20-26.

Shaat, I., M. Mabrouk, A. A. Raheem and A. Hamed (2007). Estimates of heritability and correlation for milk and growth traits in Zaraibi goat. Egyptian J. Anim. Prod, 44(2): 161-171.

Snyman, M. A. (2012). Genetic analysis of body weight in South African Angora kids and young goats. South African Journal of Animal Science, 42(2): 146-155.

Tesema, Z., M. Tilahun, B. Deribe, M. Lakew, N. Belayneh, A. Zegeye and D. Aychew (2017). Effect of non-genetic factors on pre-weaning growth, survivability and prolificacy of Central Highland $x$ Boer crossbred goats in North Eastern Ethiopia. Livestock Research for Rural Development, 29(7): 11-17.

Thomas, C. L., W. R. Lamberson, R. L. Weaber, L. S. Wilbers, T. Wuliji, J. D. Caldwell and B. C. Shanks (2016). Genetic Parameters for Internal Parasite Resistance, Reproduction, and Growth Traits in a Closed Line of Kiko $\times$ Boer Goats DivergentlySelected for Internal Parasite Resistance. Sheep \& Goat Research Journal, 31: 30-37.

Van der Werf, J. and M. Goddard (2003). Models and methods for genetic analysis. Course Notes. University of New England (UNE).

Willham, R. L. (1972). The role of maternal effects in animal breeding: III. Biometrical aspects of maternal effects in animals. Journal of Animal Science, 35(6): 1288-1293.

Yadav, J. S., M. K. Singh, B. Rai, S. K. Singh, M. C. Yadav and B. U. Khan (2005). Selection indices for growth traits in closed flock of Kutchi goats. The Indian Journal of Animal Sciences, 75(2): 226-228.

Yamada, Y., K. Yokouchi and A. Nishida (1975). Selection index when genetic gains of individual traits are of primary concern. The Japanese Journal of Genetics, 50(1): 33-41.

Zhang, C. Y., Y. Zhang, D. Q. Xu, X. Li, J. Su and L. G. Yang (2009). Genetic and phenotypic parameter estimates for growth traits in Boer goat. Livestock Science, 124(1-3): 66-71. https://doi.org/10.1016/j.livsci.2008.12.010. 


\section{الأدلة الانتخابية ذات العائد المرغوب لأوزان الجسم قبل الفطام للجديان الزرايبى في مصر

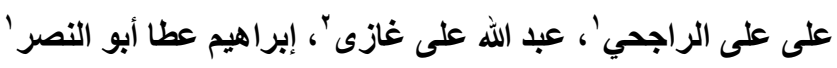

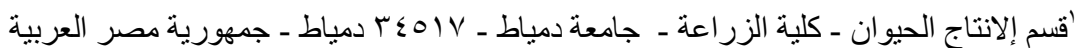

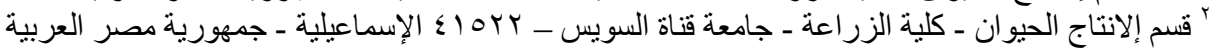

الهدف من الدراسة الحالية هو تقدير المعايير الور اثية وتقييم الأدلة الانتخابية المختلفة ذات العائد الور اثي المرغوب لأوزان الجسم قبل

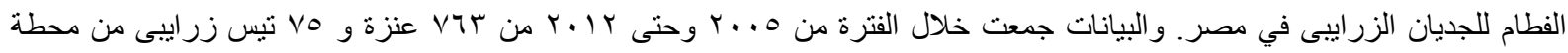
السرو البحثية التابعة لمعهد بحوث الإتناج الحيو اني. وقد أجري تحليل البيانات بطريقة REML باستخدام

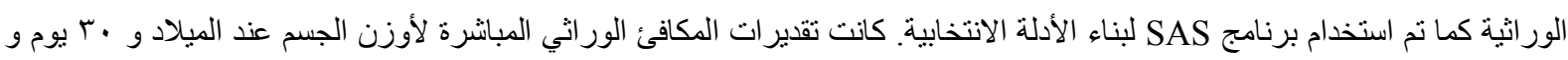

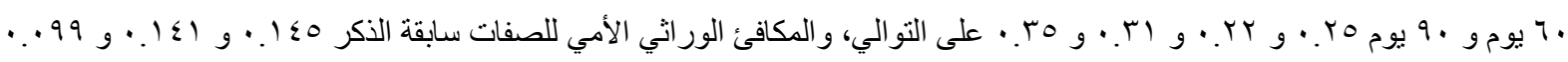

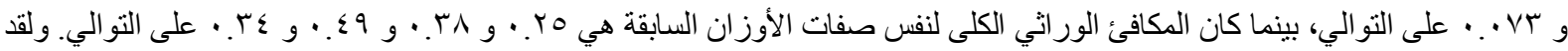

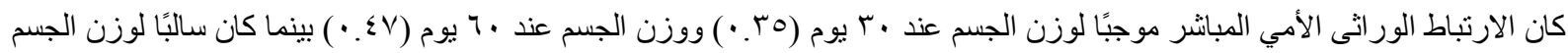

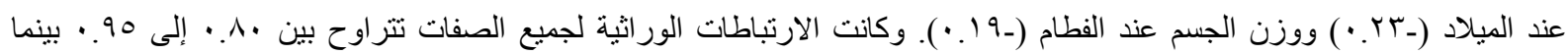
تراوحت قيم الارتباطات المظهرية بين 99.

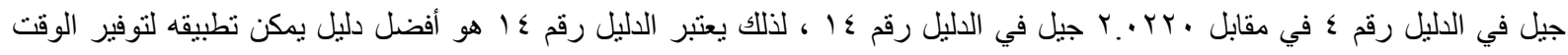
و المجهود للتحسين الور اثى للصفات المدروسة في جديان الماعز الزر ايبى في مصر. 